34. Gross. Contribution à l'étude des fibro-myomes du ligament large (Sixième Congrès de lirançais de Chirurgie. Semaine Medicale 구 19). Къ ученію о фиброміомахъ широной связки.

Плотные опухолі широкої связки встрБчаютел крайне р'вдко и мало изучены. Virchow нервый указаль на возножность црямаго развитіл фиброміомъ изъ тканеіи ппирокой связки. Schetelig, Langenbeck, Gayet, Billroth, Schroeder, Tedenert и др. наблюдали интралигаментарныя фиброміомы безъ связи съ маткой. Фиброміомы на ножкь гораздо демонстративнье, но встрьчаются еще рьже; до спхь пор' опубликовано было только 5 случаевь: Mikulic;'a, Sänger'a, Borker'a, Biflinger'a и Doran’a. Авторь удалиль фпброміому на ножкь вьсомъ 2500 граммь изъ правой шпрокой маточной связкп. По м'ьсту пронсхожденія, авторъ соглашается съ Sänger'oм'ь, считая таковымт мпшечныл волокна широкой связки. Діагностпка ставится очень трудно пा только въ случањ Breisky она была поставлена правпльно, другіе же авторы смъшивали сь опухо.лью япчнпка. Опухоли этп удаляютсл, если оны снабжены ножкой-какь яичншковыя, если же такової ныть, то онь должны быть разсматршваеми какъ подперитонеальныя опухоли щатни.

\title{
17. Садовскій.
}

\section{T. Cramer: Parametritis abscedens bei einem 12 jährigem Madchen} (Deutsche med. Wochenschr., 1892, № 33). Parametritis abscedens у 12 льтней дьвочки.

Забольваніе начпнается головными болямп, длящинися 2 дня, затьмъ. выступають на первый плань коликообразныя боли въ животь, съ. болевымп ощущеніями при пальпаціи въ ойтасти Colon descendens. Oniй только незначптельно п кратковременно уменьшаеть боль п всльдствіе этого прополаскиваніе кишечника невозможно. Пршнятіе Ol. Ricini вызываеть. рвоту. Теплыя прнпарки уменьшають колпкообразныя болш только во время прндыненія ихь. Какь только онь охлаждаютея боли усиливаются. Такой Status продолжается съ 7 сентября до 15-го, когда появилась явно сплюснутая дефекація. Діагностицпуется стенозъ кишкл. Не смотря на прим'веніе наркотическгхь средствь коликообразныя боли настолько мучительны, что ребенокъ мечется въ кроватп и крпчпть благинъ матомь. Новое изсльдовавіе ногазываеть јспленную чувствительность въ львой пахової ойластп, въ правой бользненность значительно меньше. Всльдствіе этого крон'ь стеноза кишки предполагается воспалительный процессъ брюшины этой мьстности. Изсльдованіе подь наркозоиь показало: абсцессь въ львомь заднемъ сводђ, котојый выдается болыпе кзади и вдавливаеть переднюю стьнку recti въ просвъть кишки. Пробный проколъ въ заднемъ своды. Извергаегся въ большомъ количествђ зеленый пхорозный гной. Труб́ка троакара оставляется въ отверстіи абсцесса. Назначаются теплыя ванны ш теплыя пришарки изъ льнянаго сьмени. Коликообразныя боли посль пункціп значительно уменьшаются; появился аптетить. 20 сентяб́я вновь настушапоть боли всльдствіе застоя истеченія. 23 сентяи́ря вторшная пункція. Значительное облегченіе всыхх спмпто мовъ. Въ посльдующіе дни, мъсто прокола опять заросло и боли возобнови- 